\title{
Organofosfatlı bir insektisit: Klorpirifos
}

\author{
An organophosphate insecticide: Chlorpyrifos
}

Semra Özdemir, Bahar Öztürk Kurt

İstanbul Üniversitesi-Cerrahpaşa, Cerrahpaşa Tip Fakültesi, Biyofizik Anabilim Dal, İstanbul, Türkiye

Correspondence: Semra ÖZDEMIR

İstanbul Üniversitesi-Cerrahpaşa, Cerrahpaşa Tip Fakültesi, Biyofizik Anabilim Dalı, İstanbul, Türkiye e-mail: hsf@istanbul.edu.tr
Özet

Organofosfatlı bir insektisit olan klorpirifos tarımsal alanlarda üretimi ve verimliliği arttırmada, evlerde ve çeşitli kapalı alanlarda hașere ve patojenlerin kontrolünde en fazla tercih edilen geniş spektrumlu bir böcek öldürücüdür. Elde edilebilmesinin kolaylı̆̆ı ve ucuz olması nedeniyle kontrolsüzce ve sıkça kullanılabilen klorpirifos, toprak, hava, gıda ve su gibi maruziyet yollarıyla vücuda girmekte ve hızla dağılarak özellikle yağ dokusu olmak üzere çeşitli doku ve organlarda birikmektedir. Klorpirifos insanların da dahil olduğu birçok hedef dıṣı organizmada toksisite sebebidir. Organofosfatların neden olduğu toksisitede semptomların görülme hızı ve etkinliği, organofosfata ne kadar süre ile ve hangi yolla maruz kalındığına, organofosfatın kimyasal yapısına bağlı olduğu gibi yıkım hızı ve metabolik aktivasyonda bu mekanizmada etkilidir. Klorpirifosun kolinerjik sinapslarda asetilkolinesterazın (AChE) geri dönüşümsüz inhibisyonuna bağlı nörotoksisiteyi içeren etki mekanizması, sinir sistemi üzerinde istenmeyen etkilere sebep olmaktadır. Klorpirifosun aktif metabolitleri olan 3,5,6-trikloro-2-piridinol (TCP) ve klorpirifos-oksonun yarılanma ömürlerinin klorpirifosa kıyasla daha uzun olması vücuttan atılım sürecini uzattığı için ciddi sağlık komplikasyonlarına yol açmaktadır. Klorpirifos toksisitesi nörolojik disfonksiyonlar, endokrin sistem hastalıkları ve kardiyovasküler hastalıklar ile ilișkilendirilmekle birlikte hematolojik maligniteleri, genotoksisiteyi, histopatolojik, gelişimsel ve davranışsal anomalileri ve oksidatif stresi de indükleyebilir. Ayrıca maruz kalmaya bağlı olarak göz tahriși ve dermatolojik kusurlar da görülebilmektedir. Bu derleme, klorpirifos ile ilgili çalışmalar dikkate alınarak hazırlanmış olup klorpirifosun yapısı, klorpirifosa maruz kalma yolları, klorpirifosun toksik etkilerinin oluşum ve tespit edilebilme mekanizmaları konusunda bilgiler içermektedir.

Anahtar kelimeler: Klorpirifos; İnsektisit; AChE; Toksisite

\section{Abstract}

Chlorpyrifos, an organophosphate insecticide, increases production and productivity in agricultural areas, it is a broad spectrum insecticide most preferred in the control of pests and pathogens in homes and various indoor areas. Chlorpyrifos which can be used uncontrollably and frequently due to its ease of obtainment and cheapness, enters the body through exposure ways such as soil, air, food and water, and rapidly disperses and accumulates in various tissues and organs, especially in adipose tissue. Chlorpyrifos is a cause of toxicity in many non-target organisms, including humans. The rate and effectiveness of symptoms in toxicity caused by organophosphates depend on how long and in which way the organophosphate is exposed, the chemical structure of the organophosphate, as well as the rate of destruction and metabolic activation. The mechanism of action of chlorpyrifos, which includes neurotoxicity due to irreversible inhibition of acetylcholinesterase (AChE) at cholinergic synapses, causes undesirable effects on the nervous system. The longer half-lives compared to chlorpyrifos cause serious health complications as it prolongs the excretion process from the body. Although chlorpyrifos toxicity is associated with neurological dysfunctions, endocrine system diseases and cardiovascular diseases. It can also induce hematological malignancies, genotoxicity, histopathological, developmental and behavioral abnormalities, and oxidative stress. In addition, eye irritation and dermatological defects may occur due to exposure. This review has been prepared by taking into account the studies related to chlorpyrifos and includes information on the structure of chlorpyrifos the ways of exposure to chlorpyrifos the formation and detection mechanisms of the toxic effects of chlorpyrifos

Keywords: Chlorpyrifos; Insecticide; AChE; Toxicity

Received 01.06.2021 Accepted 26.07.2021 Online published 27.07.2021 


\section{Giriș}

Pestisitler, uzun yıllardır tarım ürünlerinin işlenmesi, üretilmesi, depolanması ve pazarlanması süreçlerinde besin değeri ve verimliliğini azaltan ve pest olarak bilinen zararlı organizmaları ortadan kaldırmak, kontrol altında tutmak veya zararlarını azaltabilmek amaciyla kullanılan kimyasal madde ve bileşiklerdir. Pestisitler içindeki insektisitler grubunda organofosfatlar kimyasal özellikleri nedeniyle özel bir öneme sahiptirler. Organofosfatlı insektisitler, dünya çapında toplam insektisit kullanımının \% 50'sinden fazlasını oluşturmaktadır (1). 20182023 yılları arasında dünya çapındaki organofosfat pazarının bileşik yıllık büyüme oranının $\% 5,5$ olacağı tahmin etmektedir.

Geniş spektrumlu klorlu organofosfatlı insektisit olan klorpirifos, tarım alanlarında üretimi ve verimliliği arttırmada, ormancılık sektöründe çeşitli böcek ve patojenlerin kontrol edilmesinde, ev kullanımında ise haşerelerden korunmada dünya çapında en yaygin kullanılan organofosfatl insektisitlerdendir. Klorpirifosun termitler, pireler, yaprak bitleri, böcekler, çene böcekleri, hamam böcekleri, kesici kurtlar, pire böcekleri, mısır deliciler, toprak kurtları, keneler, çekirgeler ve sivrisineklere karşı oldukça etkili olduğu bilinmektedir. Pamuk, tahıl (misır, soya fasulyesi, buğday) ve sebze tarlalarında, findık ve meyve bahçelerinde (elma, üzüm, şeftali ve narenciye ağaçları), çimen, çayırlık alan ve süs bitkilerinde böcek ilacı olarak hem gelişmiş hem de gelişmekte olan ülkelerde sıklıkla kullanılmaktadır (2-4). Düşük maliyet ve yüksek etki sebebiyle ülkemizde de geniş ölçüde kullanılan klorpirifosun aşırı ve gereksiz kullanımı hedef dış1 organizmaların ölümü ve çevre kirliliği başta olmak üzere birçok olumsuzluğu da beraberinde getirmektedir. Klorpirifos, zararlıları kontrol etmede ve sonuç olarak mahsul verimini iyileştirmede etkili olmasına rağmen insan ve hayvan sağlığını riske edecek problemlere sebep olabilmektedir (Şekil 1). Yapılan araştırmalarda mesleki yolla, besin döngüsü yoluyla, kaza ya da intihar amaçlı maruz kalınan organofosfatların yılda ortalama 200.000 kişinin ölümüne ve yaklaşık
3 milyon kișinin zehirlenmesine neden olduğu bildirilmiştir (5).

\section{Klorpirifosun Fiziksel ve Kimyasal Özellikleri}

Klorpirifosun moleküler formülü C9H11Cl3NO3PS, molekül ağırlığı 350,59 $\mathrm{g} / \mathrm{mol}$, yoğunluğu $1,398 \mathrm{~g} / \mathrm{cm} 3$, erime noktas 1 $41,5-42,5^{\circ} \mathrm{C}$, kaynama noktas 1 ise 160 0C'dir. Klorpirifos etil [O,O-dietil-O-(3,5,6trikloro-2-piridil) fosforotiyonat] Dünya Sağlık Örgütü tarafindan orta derecede toksik - (Sınıf II) insektisid olarak sınıflandırılmıştır ve LD50 değeri 82 - $270 \mathrm{mg} / \mathrm{kg}$ olarak belirlenmiştir (6). LD50, toksik maddenin test edilen populasyonun yarısını öldürmek için gereken dozdur ve maddenin akut toksisitesini göstermek için kullanılmaktadır. Literatür çalışmalarında erkek Wistar sıçan için belirlenen oral klorpirifos LD50 değeri 135 mg / kg'dır. Ancak bu değer farklı hayvan türlerine göre değişkenlik göstermektedir $(7,8)$. Güncel literatüre göre, bu değer 66 ile $195 \mathrm{mg} \mathrm{/} \mathrm{kg} \mathrm{vücut} \mathrm{ağırlığı} \mathrm{arasında}$ değişkenlik göstermektedir (9). Klorpirifos piyasada Dursban, Lorsban, Equity, Suscon, Empire20 ve Whitmire PT270 gibi çeşitli ticari isimler altında, granül, toz ve emülsifiye konsantre formlarda satılmaktadır. Merkaptan benzeri (tiyol) kokuya sahip, renksiz, beyaz kristal toz olan klorpirifosun suda çözünürlüğü azdır $\left(0.39 \mathrm{mg} / \mathrm{L}\left(19.5^{\circ} \mathrm{C}\right)\right.$ ve 2 $\mathrm{mg} / \mathrm{L}\left(25^{\circ} \mathrm{C}\right)$ ancak misır yağı, benzen, dimetil sülfoksit, metanol, aseton, ksilen, metilen klorür ve Tween 20'de kolaylıkla çözünür. Klorprifos etil, nötral ve asidik ortamlarda kararlıdır fakat pH'ın yükseldiği ortamlarda kararlılığı azalır (10).

\section{Klorpirifosun Etki Mekanizması}

Klorpirifos etkisini organofosfatl pestisitlerin tespit edilmesinde standart bir biyolojik belirteç olarak kabul edilen AChE enziminin inhibisyonu üzerinden gösterir. Nöronlardan gelen sinyallerinin iskelet kaslarına, düz kaslara, otonom sinir düğümlerine, salg1 bezlerine, merkezi sinir sistemine iletiminin düzgün sağlanmasında önemli görevleri olan AChE, bir nörotransmitter olan asetilkolini kolin ve asetik asite çevirerek parçalayarak 
aynı zamanda asetilkolinin miktarını da düzenler (11,12). (Şekil 2) (13). AChE'nin aktif bölgesinde yer alan serin aminoasitine fosfat bağıyla bağlanan klorpirifos, geri dönüşümsüz bir inhibisyona neden olur (14). Yağda çözünen (lipofilik) yapıda olan klorpirifos kan-beyin bariyerini rahatlıkla geçer ve okson metabolitleri aracılığ beyinde kolinerjik sinapslarda AChE inhibisyonuna neden olarak etkisini gösterir (15). Klorpirifos gibi birçok organofosfatlı insektisitin yapısında fosfora çift bağlı sülfür atomu vardır. Toksik hale gelmeleri için metabolik aktivasyon ile oksonlara dönüşmeleri, yani yapılarındaki $\mathrm{P}=\mathrm{S}$ grubunun $\mathrm{P}=\mathrm{O}$ grubuna dönüşmesi gerekir. Çünkü yalnızca yapısında $\mathrm{P}=\mathrm{O}$ grubu bulunan organik fosforlu bileşikler AChE'1 baskılayabilir. Klorpirifos vücuda alındıktan sonra, oksidatif desülfürasyon yoluyla oksona metabolize edilir. Klorpirifosun oksijen ile bağlanması sonucu karaciğerde okson formuna dönüşmüş olan aktif metabolit klorpirifos-oksondur. Klorpirifosun biyotransformasyonu sitokrom P450 (CYP450) ve karaciğerin mikrozomal membranlarında yer alan ilgili enzimler aracıllı̆gıla katalizlenir. Klorpirifosun toksik metabolitleri klorpirifos-okson, TCP ve dietiltiofosfat (DETP), CYP450 aracılı̆̆ıyla gerçekleşen oksidatif desülfürasyon ve dearilasyon reaksiyonları sonucunda sirasiyla oluşur. Klorpirifosun biyoaktivasyonunun büyük kısmı karaciğerde, detoksifikasyonu ise hem karaciğer hem de plazmada gerçekleşir (16-18). Klorpirifosun vücuttaki kalıcılığı az olduğundan TCP, DETP ve dietilfosfat (DEP) gibi klorpirifos metabolitleri, kanda veya idrarda biyolojik belirteç olarak işlev görür. $\mathrm{Bu}$ metabolitlerin ölçümleri klorpirifos emiliminin in vivo değerlendirilmesine yardımcı olur. İnsektisitler nörotoksisitelerini, hedeflenen organizmanın sinir sisteminde yer alan sodyum, potasyum ve klor iyonları ile ilişkili membran transportuna, özgün enzimlere veya sinir uçlarında yer alan nörotransmitterlere müdahale ederek gösterirler.

Enzim inhibisyonu sonucu otonom ve merkezi sinir sistemlerinde, sinir-kas kavşağında, asetilkolinin birikmesi presinaptik, nikotinik ve muskarinik reseptörlerin aşırı uyarılması ile düz kaslarda kasılmaya ve salg1 bezlerinden yüksek miktarlarda salg1 üretilmesine neden olur. Açığa çıkan bu aşırı uyarıy kolinerjik sinaptik iletim felci takip eder ve bu durum kolinerjik sendrom ya da kolinerjik kriz olarak nitelendirilir (12-14). Organofosfatl insektisitlerin toksisite mekanizmaları ile hedeflediği organlar tüm organizmalarda hemen hemen aynıdır, ancak ortaya çıkan toksik etkinin şiddeti büyük oranda doza bağlıdır. AChE enziminin tekrar etkinlik gösterebilmesi için vücut içerisinde tekrardan üretilebilmesi yada oksim türü maddelerin kullanımı ile tekrar etkili hale getirilmesi gerekmektedir. Bir maddenin kanbeyin bariyerini geçme derecesi yağdaki çözünürlüğüne, serum proteinlerine bağlanma affinitesine, yüküne ve molekül ağırlığına bağlıdır. Maddenin lipofilik özelliği ne kadar fazlaysa kan-beyin bariyerinden geçişi de o kadar hızlı olur. Bunun nedeni, klorpirifos gibi nörotoksik etkisi olduğu bilinen lipofilik maddelerin, endotel hücrelerinin lipit membranlarında çabuk çözülmesi ve beyne basit difüzyon ile girmesidir (19). Timchalk ve ark. (2002) mısır yağı içinde çözdürülerek hayvan modellerine uygulanan klorpirifosun absorpsiyon seviyelerini \% 80'lere çıkardığını bildirmiştir (20). Organofosfatlı bileşikler vücuda girdikten sonra hızlıca dağılarak yağ dokusu başta olmak üzere karaciğer ve böbrek dokularında birikirler. Oral yoldan klorpirifos uygulanan sıçanların yağ dokularında diğer dokulara kıyasla fazla miktarda klorpirifos birikimi tespit edilmiştir $(21,22)$. Eaton ve ark. (2008), vücut ağırlığ 1 başına $50 \mathrm{mg}$ klorpirifosun oral yolla uygulanmasinın ardından 3 saat içinde gerçekleştirdikleri ölçümlerinde klorpirifos metabolitleri olan DEP, DETP ve TCP'nin kandaki seviyelerinin en yüksek değerde olduğunu ortaya koymuşlardır (4). Kısırlık problemi olan 322 erkeğin idrar örnekleri ile gerçekleştirilen başka bir çalışmada idrarda TCP artarken östradiol düzeylerinde doza bağlı bir azalma korelasyonu elde edilmiştir (23). Klorpirifosun ana metaboliti, idrarla atılan ve üriner klorpirifos metabolitlerinin varlığını artırabilen TCP dir. Siçanlarda tek geçişli bağırsak perfüzyon yöntemi kullanılarak klorpirifosun asimilasyonunu araştıran çalışmada klorpirifos emiliminin ince bağırsağın tamamında gerçekleştiği ve 
uygulanan klorpirifosun neredeyse \% 99'unun emildiği görülmüştür. Klorpirifos en çok karaciğer ve böbrekte birikmektedir ve oral maruziyeti takiben, çoğu memelide klorpirifos boşaltımının ana yolu idrardır (4).

\section{Klorpirifosa Maruz Kalma Yolları}

Klorpirifos kalıntıları omurgalılardan omurgasizlara kadar neredeyse tüm canlı organizmalarda tespit edilebilen geniş bir bant etkisine sahiptir. İnsanlar ve hayvanlar klorpirifosa çevresel, oral, dermal ve inhalasyon yolları başta olmak üzere çeşitli yollarla maruz kalabilirler (4, 24). Klorpirifosun bulaş yolu ve/veya ne kadar dozda alındığı vücuttaki etkinliğinde ve emiliminde belirleyicidir. Pestisitlerin çoğunlukla püskürtme yoluyla uygulanması sirasında bir miktarı yapraklara, bitki yüzeyine ve toprağa kadar ulaşıp bağlanarak toprak yapisinin bozulmasina ve burada yaşayan canlıların olumsuz şekilde etkilenmesine sebep olur. Kalan kısmı ise dağılma ve buharlaşma nedeniyle kaybolur (25). Sudaki çözünürlüğü 20-25 ${ }^{\circ} \mathrm{C}^{\prime}$ de 0,7 ila $2,0 \mathrm{mg} / \mathrm{L}$ olan pestisitler, akarsulara ve yer altı sularına, yağışlar ve sızıntı kanalları aracılığıyla karışabilirler. Bu karışma sonunda sucul ortama girerek, denizde yaşayan canlılarının zehirlenmesine ve ölümüne neden olmakla kalmayıp içme suyu kaynaklarını da kirletebilirler. Kuşlar, arılar, balıklar çeşitli mikroorganizmalar ile omurgasızlar gibi hedef dışı organizmaların üreme dengelerinde bozulmaya ve hatta ölümüne neden olabilirler. Pestisitler doğrudan toprağa uygulanma sonrasında, topraktan buharlaşma yoluyla veya rüzgâr aracilığıla atmosfere girer ve sonrasında su aracilığıyla yeraltına ulaşır. Hava aracilığıyla uzun mesafeler boyunca taşınabilir ve atmosfere giren pestisitler yağmur, sis ya da kar şeklinde yeniden yeryüzüne dönebilirler (26). Bu hidrolojik döngü sürekli olarak devam eder (Şekil 3) (27).

Çiçek yetiştiricileri, tarımsal çiftlik işçileri, fümigatörler veya pestisit uygulayıcıları, mesleki veya işyeri maruziyeti sebebiyle klorpirifosa yüksek oranda ve yaygın olarak maruz kalırlar. Öte yandan klorpirifosa eser düzeyde maruz kalanlar, mesleki maruziyet dışındaki vakaların birincil kaynağını oluşturmaktadır. Bolognesi (2003), maruziyet süresi ve pestisit konsantrasyonunun yanı sıra kişisel koruyucu ekipman kullanımının / kullanılmamasının da maruziyet sonuçlarını etkilediği sonucuna varmıştır (28). Diyet yoluyla maruz kalma, klorpirifosun mahsul uygulamalarından sonra, gida maddeleri üzerindeki ayrışmamış formunun ya da TCP gibi artık formlardaki kalıntılarının vücuda alınması ile gerçekleşir (29). Bu durum, kaçınılmaz olarak, insanları ve hayvanları, tam tahıllı gidalarda bulunan veya çeşitli işlenmiş gıda ürünlerinde görülen klorpirifos izlerine maruz bırakabilir. Mesleki maruziyet dışında klorpirifosa maruz kalmanın en önemli nedeni diyettir ve bu gerek bitkilerle gerekse çiftlik hayvanlarıla beslenme ile gerçekleşmektedir. Klorpirifosa maruz kalmış bireylerin idrarlarındaki \% 50'lik TCP artışı, temel gıda maddelerindeki klorpirifos varlığı ile açılanabilir. Al-Badrany ve ark. (2007), civciv modellemesi (7-15 gün) ile gerçekleştirdikleri çalışmalarında klorpirifosun oral uygulamasının etkilerini yedi gün boyunca incelemişlerdir (30). $5 \mathrm{mg} /$ $\mathrm{kg}, 10 \mathrm{mg} / \mathrm{kg}$ ve $20 \mathrm{mg} / \mathrm{kg}$ oral klorpirifos uygulamasindan 2 saat sonra plazma (\% 40$70)$, karaciğer (\% 31-46) ve beyinde (\% 4369) klorpirifosa bağlı kolinerjik toksisitenin geliştiğini ve klorpirifosun bu dokuların işlevselliklerini önemli ölçüde düşürdüğünü ortaya koymuşlardır. Düşük klorpirifos dozlarını (2 $\mathrm{mg} / \mathrm{kg}, 4 \mathrm{mg} / \mathrm{kg}$ ) ise lokomotor aktivitede azalmaya sebep olduğu ancak anlaml toksisite belirtilerine yol açmadığı kaydedilmiştir. Dermal yolla maruz kalma olasilığ1 ve etkinliği, oral veya inhalasyon yollarıyla karşılaştırıldığında daha azdir. Nolan ve ark. (1984), oral klorpirifos dozundan sonra, idrarda \%70 oranında TCP ölçerken dermal maruziyetten sonra idrarda tespit ettikleri TCP değerinin yalnızca \% 1 olduğunu açıklamışlardır (31). Bu sonuç, klorpirifosun dermiste yer alan keratinize tabakalar sebebiyle dermal yolla çok iyi absorbe edilemediğini, ancak ağız yoluyla alındığında hızla asimile edildiğini açıklayan önemli bir bulgudur. Griffin ve ark. (1999) oral yolla klorpirifosun \% 100'ünün dermal yolla ise metabolitlerinin \% 1'nin absorbe edilediğini bildirmişlerdir (32). Kimyasal toksisite için önemli bir yol olan dermal 
maruziyetin etkisi temas edilen cilt alanına ve maruz kalma süresine bağlıdır. Klorpirifosun dermal eliminasyon fazının oral eliminasyon fazına kıyasla yaklaşı 2 kat yarılanma ömrüne sahip olmasının sebebi olarak olası lipofilisite ve zaman fazları gösterilmektedir. Meuling ve ark. (2005), gönüllülerin kollarına 5 veya $15 \mathrm{mg}$ klorpirifos uygulayarak gerçekleştirdikleri çalışmalarında uygulama dozunun \% 42-67'sinin emilemediğini ve 4,3$5 \mathrm{mg}$ TCP'nin de idrarla atıldığını ortaya koymuşlardır. Böylece emilen tüm dozun idrarla atılmayacağını bildirmişlerdir (33). Soluma yoluyla gerçekleşen maruziyetin semptomlar1, oral ve dermal absorpsiyona kıyasla daha hızlı ortaya çıkar. Birçok ülkede klorprifosun ev ortamında kullanımı yasaklandığından, inhalasyon maruziyeti çoğunlukla sürüklenmenin bir sonucu olarak, tarımsal alanlarda (mesleki) ve/veya kırsal konutlarda kullanımından kaynaklanmaktadır. $\mathrm{Bu}$ nedenle mevcut çalışmaların çoğu, mesleki maruziyete odaklanarak yalnızca çiftlik işçilerinde ve pestisit uygulayıcılarında gerçekleştirilmektedir. Sprague Dawley sıçanlarında klorpirifos maruziyetine ilişkin kısa süreli gerçekleştirilen araştırma çalışmaları, 3 ila $5300 \mathrm{mg} / \mathrm{m} 3$ arasında değişen konsantrasyonları içermektedir. 4 saat boyunca uygulanan $5300 \mathrm{mg} \mathrm{/} \mathrm{m3'lük}$ klorpirifos dozunun, çalışma grubunun \% 80'i için ölümcül olduğunu kanıtlanmıştır (4). Diyetle alınan ürünler miktarı çok düşük de olsa bir veya birden fazla pestisit kalıntısı içerebilmekte ve bu pestisitlerin kalıntıları nedeniyle oluşan toksisite ciddi sağlık sorunlarına sebep olmaktadır. Birçok gelişmiş ülke pestisitlerin bıraktığı kalıntı değerlerinin tespit ve tayini için gıda analizlerinin yapılmasının gerekliliğini ifade etmektedir.

Kalıntı değerleri kabul edilebilir günlük miktar (ADI) olarak ifade edilen toksisite kriterleri ya da maksimum kalıntı limitleri (MRL) olarak isimlendirilen ticari standartlar ile karşılaştırılarak değerlendirilir. ADI toksisite ölçüsü iken, MRL tüm dünyada kaliteli ve sağlıklı gıda ticareti kontrolünün yapilabilmesi için hem ulusal hem de uluslararası birimlerce oluşturulmuş bir standarttır. Birçok gelişmiş ülkede olduğu gibi bizim ülkemizde de tarımsal ürünlerde bulunmasına izin verilen maksimum pestisit miktarları, Gıda, Tarım ve Hayvancılık Bakanlığı tarafından ilaç ve ürün bazında belirlenmektir. Klorpirifos kalıntıları, kan veya idrar TCP, DETP veya DEP seviyelerinin ölçümleriyle belirlenebilir. Klorpirifosun başlica reaktif metaboliti olan klorpirifos-okson organizmalar için nispeten daha toksiktir (34). Klorpirifosun toprak stabilitesi birkaç günden 4 yıla kadar değişmektedir ve bu kararlılık durumu çevresel faktörlerin yanı sıra toprağın yapısına da bağlıdır. Su ekosisteminde klorpirifosun parçalanmasına karşı oluşan kararlılık durumu topraktakine kıyasla daha fazla olduğu için su ortamında klorpirifosun kalıcılığı da fazladır.

\section{Klorpirifos Toksisitesi ve Tanı}

Klorpirifos gibi organofosfatların toksisitesinde semptomların görülme hızı ve göstereceği etki, hangi organofosfata maruz kalındığına dolayısıyla kimyasal yapısına bağlıdır. Ayrıca toksisite, organofosfata maruz kalma süresi ve hangi yollarla maruz kalındığına bağlı olarak hangi metabolik yolu izleyebileceği ve yıkım mekanizmaları gibi diğer birçok faktörle de ilişkilidir (11). İlk klinik bulgular genellikle organofosfatl1 bileşiğe maruz kalındıktan sonra 30 dakika ile 3 saat arasında görülür. Organofosfat bileşiğinin ağız yoluyla yüksek miktarda alımında ise semptomlar 5 dakika gibi kısa bir sürede ortaya çıkarken, 15 dakika sonrasında ölüm gerçekleşebilir. Dermal yolla organofosfat bileşiğine az miktarda maruz kalınması ölümcül bir tehlike yaratmazken basit belirtilerin görülmesine neden olabilir (35). Organofosfatlı insektisitler lipofilik özelliktedirler ve bundan dolayı kolaylıkla kan-beyin bariyerini geçerler (36). Klorpirifos gibi organofosfat bileşiklerinin yağ dokusunda birikmesi ve sonrasında tekrar dolaşıma geçmesi, toksisite semptomlarının gecikmesine, sistemik etki süresinin uzamasına ve hatta iyileşme sonrası klinik bulguların nüksetmesine neden olabilir. $\mathrm{Bu}$ nedenle, klorpirifostan farklı olarak yağda çözünmeyen organofosfatlı bileşiklere maruz kalınılan durumlarda semptomlar yaklaşık 12 saatlik bir süre içerisinde ortaya çıkmaya başlarken klorpirifos gibi yağda çözünen bileşikler için bu süre herhangi bir etkiye neden olmayabilir (37). Organofosfat nedenli 
zehirlenmelerde oldukça önemli olan klinik bulgular nukotinik, muskarinik ve merkezi sinir sistemi bulguları olarak 3 farklı

kategoride siniflandirilır $(38,39)$ (Tablo 1).

Tablo 1. Organofosfat zehirlenmesine bağlı klinik bulgular

\begin{tabular}{lll}
\hline Nukotinik Bulgular & Muskarinik Bulgular & Merkezi Sinir Sistemi Bulguları \\
\hline Solgunluk & Aşırı terleme & Uykusuzluk \\
Konuşma bozukluğu & Tükürük artışı & Halusinasyon \\
Hipertansiyon & Burun akıntısı & Anksiyete \\
Göz bebeklerinde büyüme & Göz yaşarması & Titreme \\
Kas zayıflığı & Bronşsalgısında artma & Mental konfüzyon \\
Kas krampları & Brokospazm & Emosyonel labilite \\
Kas seyirmeleri & Karın ağrısı & Baş ağrı̈ı \\
Solunumun baskılanması & Kusma & Baş dönmesi \\
Taşikardi & Bradikardi & Deliryum \\
Paralizi & İdrar kaçırma - İshal & Koma - Nöbet \\
\hline
\end{tabular}

İlk olarak anamnez alınması, toksisiste kaynaklı kolinerjik belirtilerin görülmesi, nefes ve varsa kusmukta hidrokarbon ya da sarımsak benzeri bir kokunun tespiti tanı koymada klinik bulgulara ek olarak değerlendirilen başlıca kriterlerdir. Zehirlenmenin tespit edilmesinden sonra, maruz kalınan pestisitin belirlenmesi ve pesitisite ait kutu veya şişenin temini, antidotlara ulaşmada ve tedavi sürecini hızlandırmada büyük kolaylık sağlar $(22,40)$. Ancak insektisit ve kolinesteraz inhibitörlerinin tamamı organofosfat olmadığından bu kriterler her zaman için çok güvenilir değildir. $\mathrm{Bu}$ nedenle laboratuvar ölçümleri ile klinik bulgulara her zaman ihtiyaç vardır. Dokularda organofosfat ve metabolitlerini ölçülebilmek için gerekli olan ölçümleri yapan laboratuvar sayısının az olması, ölçüm yapılabilse bile sonuçların geç çıkması ayrıca birçok organofosfat bileşiğinin toksik referans aralığının bilinmemesi gibi dezavantajlar söz konusudur. Alternatif bir diğer test yöntemi doku AChE enzim düzeyinin ölçümüdür.

$\mathrm{Bu}$ biyopsi gerektiren cerrahi bir yöntem olması sebebiyle oldukça zahmetlidir. Ölçüm sonucunun değerlendirilebilmesi için kişinin bazal AChE düzeyinin bilinmesi gerekir ve bu durum pek mümkün değildir. Midtling ve ark. (1985), orta ya da ciddi düzeyde zehirlenme bulguları olan hastaların AChE düzeylerinin değerlendirilmesinde laboratuvar referans aralığı kriter olarak alındığında $\mathrm{AChE}$ aktivite sonuçlarının normal sınırlar içinde olduğunu ancak hastaların kendi bazal durumuna göre değerlendirildiğinde ise bu aktivitelerin yarı yarıya azalmış olduğunu göstermişlerdir (41).

Serum ve eritrosit $\mathrm{AChE}$ ölçümleri pratikte en yaygın kullanılan yöntemlerdir. Eritrosit AChE iskelet kas1 ve sinir dokusunda bulunduğu için ölçüm sonucu periferik dokudaki, beyindeki ve kastaki AChE enzim aktivitesini de yansitır. Ancak eritrosit AChE ölçümleri organofosfat zehirlenmelerinin tespitinde daha spesifik olsa da ölçüm kolaylığı ve ulaşılabilir olması sebebiyle serum AChE ölçümleri daha çok tercih edilmektedir (42). Popülasyonda Serum AChE aktivitesi bireysel farkl11ıklar gösterdiğinden yapılan tedavi sonucu verilen cevabın değerlendirilmesinde bir referans aralığı yerine azalan veya artan serum AChE aktivitesinin tespit edilmesinin daha doğru olduğu kabul edilmektedir (40). Klinik olarak AChE aktivitesinin azalması yönündeki değişiklikler önemlidir. Maruz kalınan maddenin antikolinesteraz özelliğinin olduğunu kanitlar ve onun inhibisyon derecesi hakkında fikir verir. AChE aktivite değerinin hafif şiddetli zehirlenmelerde $\% 20$ ile $\% 50$ arasında, orta şiddetli zehirlenmelerde \%1020 , şiddetli zehirlenmelerde ise \%10'un altına düşüyor olması tanı koyma açısından önem arz eder. AChE referans değerlerinin laboratuvarlar arasında farklılık göstermesi durumunda yalancı negatif sonuçlar ortaya çıkabilmektedir (42). Organofosfat toksisitesi şüphesi ile başvuran hastalara ilk olarak yapılan rutin kan tetkiklerine ek olarak 
elektromiyografi ve elektrokardiyografi ölçümleri ile beraberinde posteroanterior akciğer grafisi çekilmelidir. Elektromiyografi'de erken dönemde saptanan tekrarlı potansiyel ile fasikülasyonlar tanıyı desteklemektedir. Pulmoner ödem elimine edilerek ve elektrokardiyografi sonucu dikkatle değerlendirilmelidir (22).

\section{Sonuç}

Bir organofosfat olan klorpirifos, g1da mahsullerinde, evlerde ve işyerlerinde böcek zararlılarının imhası için dünya çapında en yaygin kullanılan pestisitlerden biridir. Klorpirifos kullanımı 1960'larda zirveye ulaşmıştır ve 1974 ile 2005 yılları arasında klorpirifos nedeniyle zehirlendiği kaydedilen yaklaşık 278 vaka olmuştur. Genotoksisite, immünotoksisite, sitotoksisite, oksidatif stres, nörotoksisite ve mutajenite gibi toksik etkileri göz önüne alındığında, bazı ülkelerde klorpirifosun yasaklanması durumları doğmuştur. EPA, 2011 y1lında kapsamlı bir insan sağlığ1 risk değerlendirmesi gerçekleştirmiş, 2014 ve 2016 'da revize etmiş ve nihayetinde 2018'de klorpirifos kullanımının yasaklanmasına ilișkin ABD mahkemesinden karar çıkartmıştır. Kalıntı formdaki kalıcılığı ve etkinliği nedeniyle gelişmekte olan ülkelerde kullanımı halen büyük ölçekte devam etmekte olan bu

\section{KAYNAKLAR}

1. Yang KJ, Lee J, Park HL. Organophosphate pesticide exposure and breast cancer risk: a rapid review of human, animal, and cell-based studies. Int $J$ Environ Res Public Health. 2020;17: 5030.

2. EPA, 2000. Human Risk Assessment: Chlorpyrifos. US Environ, Protection Agency.

1. ATSDR, 1997. Toxicological Profile for Chlorpyrifos Agency for Toxic Substances and Disease Registry.

2. Eaton DL, Daroff RB, Autrup H, et al. Review of the toxicology of chlorpyrifos with an emphasis on human exposure and neurodevelopment. Crit Rev Toxicol. 2008; 38: 1-125.

3. Jeyaraatnam J. Acute pesticide poisoning: a major global health problem. World Health Stat Q. 1990; 43: 139-144. insektisitin gıda ve sağlık güvenliği açısından yeniden değerlendirilmesi ve düzenlenmesi gerekmektedir. Dünya nüfusunun giderek artıyor olması ve kullanılabilir tarım alanlarının azalması nedeniyle, pestisit kullanımı olmadan tarım ekonomisini sürdürmek ve nüfusunun yeterli beslenmesini sağlamak gittikçe imkansız hale gelmektedir. Bir yandan nüfus artışı ve ihtiyaçları temin etmek adına yapılan girişimler, diğer yandan teknolojik ve endüstriyel alandaki gelişmeler havada, toprakta ve suda kirliliğin artışına yol açmaktadır. Gidalardaki klorpirifos konsantrasyonlarının azaltılmasında etkili işlemlerin geliştirilmesi oldukça önemlidir. $\mathrm{Bu}$ amaçla gıdalardaki kalıntı miktarının kısa sürede tespit edilebilmesini sağlayabilecek sensör mekanizmalarının geliştirilmesi ve kullanılması büyük bir gereklilik olarak görülmektedir. Pestisit kaynaklı sağlık sorunlarının üstesinden gelebilmek ve toksisiteyi önleyebilmek adına gerçekleştirilen çalışmalar insan sağlığ birçok canlı için önem arz etmektedir klorpirifosun diğer organofosfat pestisitlerine göre avantajlı kullanımının desteklenebilmesi için potansiyel toksisitesi ve güvenliği hakkındaki tüm soru işaretlerinin giderilmesi gerekmektedir. Bunun için uygun kantitatif testler ile gerçekleştirilmiş yeterli sayıda hayvan deneyleri ve ileriye dönük insan çalışmalarına ihtiyaç duyulmaktadır.
4. World Health Organization (WHO). Who specifications and evaluations for public health pesticides. 1997;42-44.

5. Goel A, Dani V, Dhawan DK. Zinc mediates normalization of hepatic drug metabolizing enzymes in chlorpyrifos induced toxicity. Toxicol Lett. 2007; 169: 26-33.

6. Ozturk Kurt B, Konukoğlu D, Kalayci R, et al. Investigation of the protective role of selenium in the changes caused by chlorpyrifos in trace elements, biochemical and hematological parameters in rats. Biol Trace Elem Res. 2021; Feb 10.

7. Kopjar N, Žunec S, Mendaš G, Micek V, et al. Evaluation of chlorpyrifos toxicity through a 28-day study: cholinesterase activity, oxidative stress responses, parent compound/metabolite levels, and primary DNA damage in blood and brain tissue of 
adult male Wistar rats. Chem Biol Interact. 2018; 279: 51-63.

8. Rathod A, Garg R. Chlorpyrifos poisoning and its implications in human fatal cases: a forensic perspective with reference to Indian scenario. J Forensic Legal Med. 2017; 47: 29-34.

9. Demirdöğen BC. Organofosfatl1-pestisitzehirlenmeleri ve serum paraoksonaz 1 (Pon1) enziminin organofosfat metabolizmasındaki rolü. Turk Hij Den Biyol Derg. 2010; 67: 97-112.

10. Katz KD, Brooks DE. (2009). Organophosphate Toxicity. In: Medscape. Editors: Talavera F, Tarabar A, Kirkland L,http://emedicine.medscape.com/article/1 67726- overview (Erişim tarihi: 10.12.2009)

11. İnternet:URL:http://faculty.pasadena.edu/d kwon/chap\%208_files/textmostly/slide 58 . html, Son Erişim Tarihi: 21.02.2015

12. Robey WC, Meggs WJ.. Insecticides, Herbicides and Rodenticides. Tintinalli JE, Kelen GD, Stapczynski JS, eds. Emergency Medicine (6th ed): a Comprehensive Study Guide. McGraw Hill Company, New York, 2004:11341143.

13. Jortner BS. Effect of stress at dosing on organophosphate and heavy metal toxicity. Toxico Appl Pharm. 2008; 233: 162-167.

14. Ma T, Chambers JE. Kinetic Parameters of Desulfuration and Dearilation of Parathion and Chlorpyrifos by Rat liver Microsomes. Food Chem Toxicol. 1994; 32: 763-767.

15. Timchalk C, Busby A, Campbel, JA, et al. Comparative pharmacokinetics of the organophosphorus insecticide chlorpyrifos and its major metabolites diethylphosphate, diethylthiophosphate and 3,5,6-trichloro-2-pyridinol in the rat. Toxicol. 2007; 237: 145-157.

16. Heilmair R, Eyer F, Eyer P. Enzyme-based assay for quantification of chlorpyrifos oxon in human plasma. Toxicol Lett. 2008; 181: 19-24.

17. Pardridge WM. Drug delivery to the brain. J Cereb Blood Flow Metab. 1997; 17: 713731.

18. Timchalk C, Nolan RJ, Mendrala AL, et al. A physiologically based pharmacokinetic and pharmacodynamic (PBPK/PD) model for the organophosphate insecticide chlorpyrifos in rats and humans. Toxicol Sci. 2002; 66:34-53.

19. Güven M, Sungur M. Organophosphorus poisonings and future directions. Curr Topics in Toxicol. 2005; 2: 57-65.

20. Joshi S, Biswas B, Malla G. Management of organophosphorus poisoning. Update in Anaesth. 2005; 19: 1-2.

21. Meeker JD, Ravi SR, Barr DB, et al. Circulating estradiol in men is inversely related to urinary metabolites of nonpersistent insecticides. Reprod Toxicol. 2008; 25:184-191.

22. Uchendu C, Ambali SF, Ayo JO. The organophosphate chlorpyrifos, oxidative stress and the role of some antioxidants: a review. Afr J Agric Res. 2012; 7 (18): 2720-2728

23. Kiziewicz B, Czeczuga B. Bioaccumulation of organochlorine pesticides in the trophic chain algafreshwater fish. Acta Ichthyolog et Piscator. 2002; 32: 41-51.

24. Tankiewicz M, Fenik J, Biziuk M. Determination of organophosphorus and organonitrogen pesticides in water samples. Trends Analyt Chem. 2010; 29: 1050-1063.

25. Eleršek T, Filipič M.. Organophosphorus pesticides mechanisms of their toxicity. In M. Stoytcheva (Ed.). Pesticides-the impacts of pesticide exposure. London: InTech. 2011:243-260.

26. Bolognesi C. Genotoxicity of pesticides: a review of human biomonitoring studies. Mutat Res. 2003; 543: 251-272.

27. Han C, Zhu LS, Wang J, et al. Residue analysis of chlorpyrifos and its toxic metabolite TCP in water by HPLC. $J$ AgoEnviron Sci. 2009; 28:1552-1556.

28. Al-Badrany YMA, Mohammad FK. Effects of acute and repeated exposure to the organophosphate insecticide chlorpyrifos in open field activity in chicks. Toxicol Lett. 2007; 174: 110-116.

29. Nolan RJ, Rich DL, Freshour NL, et al. Chlorpyrifos: pharmacokinetics in human volunteers following single oral and dermal doses. Toxicol App Pharmacol.1984; 73: 8-15.

30. Griffin P, Mason H, Heywood K. Oral and dermal absorption of chlorpyrifos: a human volunteer study. Occup Environ Med. 1999; 56: 10-13.

31. Meuling WJ, Ravensberg LC, Roza L, et al. Dermal absorption of chlorpyrifos in human volunteers. Int Arch Occup Environ Health. 2005; 78:44-50.

32. Supreeth M, Raju NS. Biotransformation of chlorpyrifos and endosulfan by bacteria and fungi. Appl Microbiol Biotechnol. 2017; 101: 5961-5971.

33. Kara IH, Guloglu C, Karabulut A, et al. Sociodemographic, clinical, and laboratory features of cases of organic phosphorus intoxication who attended the Emergency Department in the Southeast Anatolian Region of Turkey. Environ Res. 2002; 88: 82-88.

34. Vale A, Lotti M. Organophosphorus and carbamate insecticide poisoning. Handb Clin Neurol. 2015; 131: 149-168.

35. Willems JL, De Bisschop HC, Verstraete $\mathrm{AG}$, et al. Cholinesterase reactivation in 
organophosphorus poisoned patients depends on the plasma concentrations of the oxime pralidoxime methylsulphate and of the organophosphate. Arch Toxicol. 1993; 67: 79-84.

36. Clark RF. Insecticides: organic phosphorus compounds and carbamates. Goldfrank's Toxicological Emergencies. (7th ed.) McGraw-Hill Professional; New York, 2002:1346-1360.

37. Robey WC, Meggs WJ. (2000). Insecticides, herbicides, rodenticides. Emergency Medicine. (5 nd ed), McGraw Hill Company, New York, 1174-1176.

38. Brahmi N, Mokline A, Kouraichi N, et.al. Prognostic value of human erythrocyte acetyl cholinesterase in acute organophosphate poisoning. Am J Emerg Med. 2006 Nov; 24:822-827.

39. Midtling JE, Barnett PG, Coye MJ, et al Clinical management of field worker organophosphate poisoning. West $J$ Med. 1985; 142: 514-518.

40. Alp H, Karakuş A, Çelik MM, et al. Organofosfat Zehirlenmesinde Yeni Bir Tedavi Yaklaşımı: Fitoterapi. Mustafa Kemal Üniv Tip Derg. 2012; 3:9. 